ISSN: 2252-7893, Vol 2, No 32013 (hal 227-237)

http://jurnal.fkip.uns.ac.id/index.php/sains

\title{
PEMBELAJARAN KIMIA BERBASIS MASALAH DENGAN METODE PROYEK DAN EKSPERIMEN DITINJAU DARI KREATIVITAS DAN KETERAMPILAN MENGGUNAKAN
} ALAT LABORATORIUM

\author{
Chairunisa Ayu Saputri ${ }^{1}$, Masykuri ${ }^{2}$, Ashadi $^{3}$, Haryono $^{4}$ \\ ${ }^{1}$ Program Studi Pendidikan Sains, Program Pascasarjana, Universitas Sebelas Maret \\ Surakarta, 57126, Indonesia \\ niez_maniez88@yahoo.com \\ ${ }^{2}$ Program Studi Pendidikan Sains, Program Pascasarjana, Universitas Sebelas Maret \\ Surakarta, 57126, Indonesia \\ mmasykuri@yahoo.com \\ ${ }^{3}$ Program Studi Pendidikan Sains, Program Pascasarjana, Universitas Sebelas Maret \\ Surakarta, 57126, Indonesia \\ ashadi_uns@yahoo.com
}

\begin{abstract}
Abstrak
Penelitian ini bertujuan untuk mengetahui pengaruh pembelajaran kimia berbasis masalah dengan metode proyek dan eksperimen, kreativitas, dan keterampilan menggunakan alat laboratorium serta interaksinya terhadap prestasi belajar. Penelitian ini dilakukan di SMAN 1 Ponorogo kelas XI IPA tahun ajaran 2012/2013. Sampel diambil menggunakan teknik cluster random sampling. Teknik pengolahan data menggunakan ANAVA tiga jalan. Hasil penelitian menunjukkan bahwa: 1) ada pengaruh penerapan pembelajaran kimia berbasis masalah dengan metode proyek dan eksperimen terhadap prestasi belajar kognitif siswa, namun tidak ada pengaruh terhadap prestasi belajar afektif; 2) tidak ada pengaruh kreativitas terhadap prestasi belajar kognitif dan afektif siswa; 3) ada pengaruh keterampilan menggunakan alat laboratorium terhadap prestasi belajar kognitif siswa, namun tidak ada pengaruh pada prestasi belajar afektif; 4) tidak ada interaksi antara pembelajaran kimia berbasis masalah menggunakan metode proyek dan eksperimen dengan kreativitas terhadap prestasi belajar kognitif dan afektif siswa; 5) ada interaksi antara pembelajaran kimia berbasis masalah menggunakan metode proyek dan eksperimen dengan keterampilan menggunakan alat laboratorium terhadap prestasi belajar kognitif siswa, namun tidak ada interaksi terhadap prestasi belajar afektif; 6) ada interaksi antara kreativitas dan keterampilan menggunakan alat laboratorium terhadap prestasi kognitif siswa, namun tidak ada interaksi pada prestasi afektif; 7) tidak ada interaksi antara pembelajaran kimia berbasis masalah menggunakan metode proyek dan eksperimen, kreativitas dengan keterampilan menggunakan alat laboratorium terhadap prestasi kognitif dan afektif siswa.
\end{abstract}

Kata kunci : PBL, proyek, eksperimen, kreativitas, keterampilan menggunakan alat laboratorium

\section{Pendahuluan}

Menghadapi tantangan masa depan yang semakin kompleks, pemerintah terus mengupayakan peningkatan kualitas sumber daya manusia di Indonesia. Salah satu cara adalah dengan meningkatkan kualitas pendidikan di Indonesia. Peningkatan

kualitas pendidikan yang telah dilakukan diantaranya penyempurnaan kurikulum, pengadaan buku paket dan peningkatan kualitas tenaga pengajar. Kurikulum Tingkat Satuan Pendidikan (KTSP) tahun 2006 merupakan pencerminan dari perencanaan, pelaksanaan dan 
ISSN: 2252-7893, Vol 2, No 32013 (hal 227-237)

http://jurnal.fkip.uns.ac.id/index.php/sains

pengawasan pendidikan dalam rangka mewujudkan pendidikan nasional yang bermutu yang diatur dalam standar nasional yang salah satunya mencakup standar proses dalam Peraturan Menteri No. 4 Tahun 2007, menyatakan tentang pembelajaran yang ideal adalah proses pembelajaran yang interaktif, inspiratif, menyenangkan, menantang, memotivasi peserta didik untuk berpartisipasi aktif, serta memberikan ruang yang cukup bagi prakarsa, kreativitas, kemandirian sesuai bakat, minat, dan perkembangan fisik serta psikologis peserta didik.

Pemerintah mengharapkan pembelajaran yang ideal di dalam kelas. Adanya anggapan keliru dari sebagian guru bahwa pengetahuan dapat dipindahkan secara utuh dari pikiran pengajar (guru) kepada siswa. Implikasinya, dalam kegiatan belajar mengajar guru mendominasi dengan metode ceramah dan tidak melibatkan siswa secara aktif dalam proses pembelajaran. Rendahnya kualitas pembelajaran mengakibatkan prestasi belajar siswa yang cenderung rendah pula, khususnya pada mata pelajaran kimia.

Mata pelajaran kimia oleh sebagian siswa masih dianggap sebagai pelajaran yang sulit dipahami. Hal ini disebabkan banyak konsep-konsep kimia yang bersifat abstrak dan merupakan mata pelajaran yang secara khusus baru dipelajari pada tingkat SMA/MA. Materi kimia khusunya laju reaksi merupakan materi yang di dalamnya banyak terdapat pembuktianpembuktian teori secara laboratoris dan ada beberapa konsep yang dapat dianalogikan dalam kehidupan seharihari. Hal ini merupakan tantangan bagi pengajar untuk menentukan model pembelajaran yang tepat agar indikator pembelajaran yang telah ditentukan dapat tercapai secara efektif dan efisien.

$$
\text { Model }
$$
pembelajaran

konstruktivis dapat diterapkan dalam usaha peningkatan hasil belajar siswa. Pembelajaran yang berlandaskan konstruktivistik merupakan pembelajaran yang menekankan pada pentingnya keaktifan siswa untuk membangun sendiri konsep dasar pengetahuannya. Proses mengkonstruksi pengetahuan tersebut melalui interaksi dengan objek, fenomena, pengalaman, dan lingkungan. Pengetahuan tidak dapat ditransfer begitu saja dari seseorang kepada orang lain tetapi harus di interprestasikan sendiri oleh masingmasing orang. Ada beberapa metode pembelajaran yang melibatkan siswa secara aktif antara lain, inkuri, demonstrasi, eksperimen, proyek dan sebagainya.

Tan cit. Rusman (2010) menyatakan bahwa pembelajaran berbasis masalah (PBL) merupakan inovasi dalam pembelajaran. Dalam PBL kemampuan berfikir siswa benarbenar dioptimalisasikan melalui proses kerja kelompok atau tim yang sistematis. Pembelajaran ini tidak mengharapkan siswa hanya sekedar mendengarkan, melihat, mencatat, dan menghafal materi pelajaran tetapi siswa aktif berpikir, berkomunikasi, mencari dan mengolah data serta menyimpulkan. Aktivitas pembelajaran diarahkan untuk menyelesaikan masalah. Pemecahan masalah dilakukan dengan menggunakan berpikir secara ilmiah. Menurut Arends (2007) pembelajaran berbasis masalah dimulai dengan mengorientasikan siswa pada masalah, mengorganisasi siswa untuk meneliti, membantu siswa menginvestigasi, membimbing dan menyajikan hasil karya dan menganalisis serta mengevaluasi proses pemecahan masalah. Pada tahapan investigasi ini diterapkan dengan metode proyek dan eksperimen.

Menurut Suparno (2007) metode proyek merupakan gabungan dari berbagai model pembelajaran seperti inquiry, discovery, belajar bersama dan sebagainya. Metode proyek merupakan suatu metode instruksional yang melibatkan penggunaan alat dan bahan yang diusahakan oleh siswa secara perseorangan atau kelompok 
ISSN: 2252-7893, Vol 2, No 32013 (hal 227-237)

http://jurnal.fkip.uns.ac.id/index.php/sains

kecil siswa, untuk mencari jawaban terhadap suatu masalah dengan perpaduan teori-teori dari berbagai bidang studi. Konsep dan karakteristik pembelajaran berbasis proyek adalah sebuah model atau pendekatan pembelajaran yang inovatif, yang menekankan belajar kontekstual melalui kegiatan-kegiatan yang komplek. Fokus pembelajaran terletak pada konsepkonsep dan prinsip-prinsip inti dari suatu disiplin studi, melibatkan pebelajar dalam investigasi pemecahan masalah dan kegiatan tugas-tugas bermakna yang lain, memberi kesempatan pebelajar bekerja secara otonom mengkonstruk pengetahuan mereka sendiri, dan mencapai puncaknya menghasilkan produk nyata.

Metode eksperimen adalah metode mengajar yang mengajak siswa untuk melakukan percobaan sebagai pembuktian, pengecekan bahwa teori yang sudah dibicarakan itu memang benar (Suparno, 2007). Metode eksperimen dibedakan menjadi dua yaitu: 1) eksperimen terbimbing; 2) eksperimen bebas. Dalam eksperimen terbimbing seluruh langkah-langkah percobaan telah dirancang oleh guru sebelumnya. Metode eksperimen bebas adalah metode eksperimen yang dilakukan guru dengan tidak memberikan petunjuk percobaan secara terperinci. Dengan kata lain siswa harus lebih banyak berfikir sendiri untuk merangkai alat, mengamati proses, mengukur, menganalisis, dan menyimpulkan.

Beberapa teori belajar yang mendukung adalah teori belajar konstruktivisme, Piaget, Vygotsky, dan Ausubel. Teori belajar konstruktivistik menyatakan bahwa siswa harus dapat membangun pengetahuannya sendiri. Pengetahuan merupakan konstruksi kognitif seseorang terhadap objek, pengalaman maupun lingkungannya. Menurut Sagala (2010), Piaget berpendapat terdapat dua proses yang terjadi dalam perkembangan dan pertumbuhan kognitif anak antara lain:
(1) proses assimilation; pada tahap ini anak menyesuaikan atau mencocokkan informasi yang baru dengan apa yang ia ketahui dengan mengubahnya bila perlu; (2) proses accommodation; pada tahap ini anak menyusun dan membangun kembali atau mengubah apa yang telah diketahui sebelumnya sehingga informasi yang baru dapat disesuaikan dengan lebih baik.

Inti belajar dari Ausubel cit. Dahar (1989) adalah belajar bermakna, merupakan suatu proses mengaitkan infromasi baru pada konsep-konsep relevan yang terdapat dalam struktur kognitif seseorang. Dalam belajar bermakna infomasi baru diasimilasikan pada sumber-sumber relevan yang telah ada dalam struktur kognitif. Teori belajar Vygotsky mengemukakan tentang Zone Proximal Development (ZPD) dan Scaffolding diungkapkan oleh Slavin (1994). ZPD adalah tingkat perkembangan sedikit di atas tingkat perkembangan seseorang saat ini. Konsep Scaffolding berarti memberikan kepada siswa sejumlah besar bantuan selama tahap-tahap awal pembelajaran kemudian mengurangi bantuan tersebut dan memberikan kesempatan kepada anak tersebut mengambil alih tanggung jawab.

Selain model pembelajaran yang digunakan terdapat beberapa faktor yang diduga dapat mendukung siswa dalam pelaksanaan pembelajaran. Pada penelitian ini digunakan kreativitas dan keterampilan menggunakan alat laboratorium. Munandar (2009) menyatakan bahwa kreativitas adalah suatu proses yang tercermin dari kelancaran, kelenturan dan orisinalitas dalam berpikir. Orang yang kreatif cenderung memiliki sikap selalu ingin tahu, memiliki minat yang luas, memiliki kegembiraan dan menyukai aktivitas yang kreatif. Dengan memiliki kemampuan kreatif, siswa tidak hanya menerima informasi dari guru, namun siswa akan berusaha mencari dan memberikan informasi dalam proses pembelajaran. 
Margono (2000) menyatakan bahwa keberhasilan suatu percobaan atau eksperimen kerap kali tergantung pada kemampuan memilih dan menggunakan alat dengan tepat. Keterampilan menggunakan alat meliputi keterampilan memilih alat-alat, mempersiapkan alat-alat, merangkai alat, menggunakan alat untuk tujuan percobaan.

Penelitian ini bertujuan untuk mengetahui pengaruh penerapan pembelajaran berbasis masalah dengan metode proyek dan eksperimen, kreativitas, keterampilan menggunakan alat laboratorium, serta interaksi antar variabelnya terhadap prestasi belajar siswa.

\section{Metode Penelitian}

Metode penelitian yang digunakan adalah metode eksperimen, dengan dua kelompok eksperimen. Kelompok pertama diberi perlakuan menggunakan pembelajaran berbasis masalah dengan metode proyek, sedangkan kelompok kedua diberi perlakuan pembelajaran berbasis masalah dengan metode eksperimen. Sebelum proses belajar mengajar dimulai siswa terlebih dahulu dilakukan observasi keterampilan menggunakan alat laboratorium dan diberikan tes kreativitas. Data skor keterampilan menggunakan alat laboratorium dan kreativitas dibagi menjadi dua kategori, yaitu tinggi dan rendah. Desain faktorial penelitian ini adalah $2 \times 2 \times 2$.

Sebagai populasinya adalah seluruh siswa yang ada di SMAN 1 Ponorogo kelas XI IPA pada tahun pelajaran 2012/2013. Teknik pengambilan sampel yang digunakan adalah cluster random sampling. Sebagai variabel bebas adalah metode proyek dan eksperimen, variabel moderator keterampilan menggunakan alat laboratorium dan kreativitas siswa. Variabel terikat adalah prestasi belajar siswa dalam materi laju reaksi. Aspek yang dinilai adalah aspek kognitif dan afektif.
Data yang dianalisis adalah data: keterampilan menggunakan alat laboratorium, kreativitas siswa, prestasi belajar kognitif dan afektif. Teknik pengumpulan data yang digunakan dalam penelitian ini adalah: 1) teknik tes untuk prestasi kognitif dan kreativitas; 2) teknik non tes yaitu angket untuk menilai ranah prestasi afektif; 3) teknik pengamatan/observasi saat melakukan percobaan untuk keterampilan menggunakan alat laboratorium

Instrumen pelaksanaan penelitian yang digunakan berupa silabus, Rencana Pelaksanaan Pembelajaran (RPP), dan Lembar Kerja Siswa (LKS). Untuk menjamin validitas isi instrumen pelaksanaan penelitian ini, dilakukan dengan menyusun kisi-kisi dan telah divalidasi oleh ahli serta dilakukan uji coba sebelum digunakan untuk pengambilan data. Uji normalitas data hasil penelitian menggunakan Kolmogorov-Smirnov dan uji homogenitas menggunakan Levene's Test.

\section{Hasil Penelitian dan Pembahasan}

Tabel 1 menyajikan data hasil pembelajaran kimia berbasis masalah dengan metode proyek dan eksperimen, keterampilan menggunakan alat laboratorium, serta kreativitas terhadap prestasi belajar.

Tabel 1. Perbandingan Prestasi Belajar Siswa pada Materi Laju Reaksi

\begin{tabular}{lll} 
& \multicolumn{2}{c}{ NILAI } \\
\cline { 2 - 3 } Metode & Kognitif & Afektif \\
\hline Proyek & 76,5 & 115,3 \\
Eksperimen & 71,8 & 113,7 \\
\hline Kreativitas & Kognitif & Afektif \\
\hline Tinggi & 75,6 & 115,2 \\
Rendah & 72,6 & 113,7 \\
\hline Keterampilan Menggunakan & Kognitif & Afektif \\
\hline Alat Laboratorium & 79,3 & 115,6 \\
Tinggi & 70,1 & 113,2 \\
Rendah & & \\
\hline
\end{tabular}


ISSN: 2252-7893, Vol 2, No 32013 (hal 227-237)

http://jurnal.fkip.uns.ac.id/index.php/sains

\section{Hasil Uji Hipotesis}

Hasil pengujian hipotesis terhadap prestasi belajar kognitif dan afektif disajikan pada Tabel 2 dan 3.

Tabel 2. Ringkasan Uji Hipotesis Prestasi Kognitif

\begin{tabular}{cccc}
\hline Hipotesis & Signifikansi & $\begin{array}{c}\text { Taraf } \\
\text { Signifikansi }\end{array}$ & $\begin{array}{c}\text { Keputusan } \\
\text { Uji }\end{array}$ \\
\hline 1 & 0,046 & 0,05 & Ho ditolak \\
2 & 0,665 & 0,05 & Ho diterima \\
3 & 0,001 & 0,05 & Ho ditolak \\
4 & 0,736 & 0,05 & Ho diterima \\
5 & 0,028 & 0,05 & Ho ditolak \\
6 & 0,044 & 0,05 & Ho ditolak \\
7 & 0,451 & 0,05 & Ho diterima \\
\hline
\end{tabular}

Tabel 3. Ringkasan Uji Hipotesis Prestasi Afektif

\begin{tabular}{cccc}
\hline Hipotesis & Signifikansi & $\begin{array}{c}\text { Taraf } \\
\text { Signifikansi }\end{array}$ & $\begin{array}{c}\text { Keputusan } \\
\text { Uji }\end{array}$ \\
\hline 1 & 0,274 & 0,05 & Ho diterima \\
2 & 0,231 & 0,05 & Ho diterima \\
3 & 0,672 & 0,05 & Ho diterima \\
4 & 0,016 & 0,05 & Ho ditolak \\
5 & 0,075 & 0,05 & Ho diterima \\
6 & 0,975 & 0,05 & Ho diterima \\
7 & 0,475 & 0,05 & Ho diterima \\
\hline
\end{tabular}

\section{Pengaruh pembelajaran kimia berbasis masalah dengan metode proyek dan eksperimen terhadap prestasi belajar siswa}

Hasil penelitian menunjukkan bahwa ada pengaruh metode terhadap prestasi belajar kognitif siswa. Diperoleh data hasil penelitian yaitu rerata dengan metode proyek dan eksperimen berturut-turut adalah 76,5 $(\mathrm{SD}=11,6) \quad$ dan $\quad 72,8 \quad(\mathrm{SD}=13,7)$. Ebrahimi (2012) dalam penelitiannya mengungkapkan bahwa pembelajaran yang melibatkan siswa aktif memberikan prestasi belajar yang lebih baik dibandingkan dengan pembelajaran yang berpusat pada guru. Di sisi lain Sola et al. (2007) dalam jurnalnya menyatakan bahwa ada pengaruh yang signifikan terhadap prestasi belajar siswa jika dalam proses penyampaian materi kimia digunakan metode dengan adanya proses penyelesaian masalah, kegiatan eksperimen laboratorium dan siswa diberikan kegiatan proyek dalam kelompok kecil.

Pembelajaran dalam laboratorium merupakan hal yang penting dalam pembelajaran sains. Studi tentang pembelajaran sains menunjukkan bahwa siswa belajar lebih banyak ketika mereka diberi kesempatan untuk belajar dengan "melakukan" daripada siswa hanya berkesempatan untuk mengamati. Hofsten et al. (2003) menyatakan bahwa kegiatan belajar sains jika dilakukan dalam kelompok-kelompok kecil (kolaboratif) akan menghasilkan prestasi belajar yang lebih baik daripada dilakukan secara individual. Hal ini terjadi karena adanya interaksi sosial di antara anggota kelompok.

Dalam penelitian ini digunakan pembelajaran kimia berbasis masalah dengan metode proyek dan eksperimen. Bilgin (2009) menyatakan bahwa tujuan pembelajaran berbasis masalah adalah menjadikan siswa berfikir lebih aktif dalam belajar dan tidak hanya memperoleh pengetahuan dari guru. Beberapa tahapan dalam pembelajaran berbasis masalah dimulai dengan pemberian masalah pada siswa, mengorganisasikan siswa untuk meneliti, memberikan kesempatan siswa melakukan investigasi, pada tahapan proses investigasi inilah digunakan metode proyek dan metode eksperimen, tahap selanjutnya adalah penyajikan hasil karya dan yang terakhir adalah menganalisis, mengevaluasi, serta menarik kesimpulan dari proses penyelesaian masalah yang telah dilakukan.

Fakta menunjukkan bahwa metode proyek memberikan hasil rerata lebih tinggi dibandingkan dengan metode eksperimen. Pada hasil penelitian yang dilakukan Sola et al. (2007) menunjukkan bahwa penerapan 
ISSN: 2252-7893, Vol 2, No 32013 (hal 227-237)

http://jurnal.fkip.uns.ac.id/index.php/sains

metode proyek memberikan hasil prestasi belajar yang baik. Metode ini lebih lebih memotivasi keingintahuan dan keinginan siswa untuk belajar. Siswa lebih banyak mengemukakan pendapat dalam kelompoknya dalam upaya menyelesaikan masalah. Pada penelitian ini berpusat pada pembelajaran dalam laboratorium sehingga siswa dapat secara leluasa membuktikan sendiri secara konkret dalam proses investigasi.

Teori belajar konstruktivistik menekankan bahwa siswa membangun pengetahuannya sendiri pada struktur kognitifnya. Pada pembelajaran menggunakan metode eksperimen siswa akan lebih dibimbing dalam melakukan penyelesaian permasalahan, sedangkan metode proyek siswa dituntut untuk lebih mandiri dan berusaha bersama kelompoknya dalam menjawab pertanyaan yang diberikan. Berkaitan dengan teori Piaget, pembelajaran berbasis masalah dengan metode proyek maupun eksperimen memberikan kesempatan pada siswa untuk berinteraksi antar siswa dan dengan sumber belajar dengan mengintegrasikan ide, data dan keseluruhan informasi yang mereka peroleh. Pengetahuan yang terbangun ini merupakan hasil dari ide, data hasil percobaan serta informasi lain yang diperoleh selama proses pembelajaran. Adanya dua metode yang diberikan, siswa dituntut untuk dapat membangun pengetahuannya sendiri dengan bantuan pengetahuan yang telah didapat sebelumnya baik secara asimilasi maupun dengan akomodasi.

Pada penelitian ini siswa diberikan masalah yang sedikit lebih sulit dari pengetahuan yang telah dimilikinya. Untuk menyelesaikan masalah yang diberikan siswa diberikan sedikit bantuan untuk mendorong siswa agar lebih aktif dalam menjawab poermasalahan baik dengan metode proyek maupun eksperimen. Pada metode eksperimen siswa telah dibantu sepenuhnya dalam usaha menyelesaikan permasalahan yang diberikan. Langkahlangkah percobaan telah diberikan sehingga siswa hanya melakukan yang telah ada pada petunjuk. Pada metode proyek siswa diberikan permasalahan yang belum pernah diketahui sebelumnya sehingga siswa tertarik untuk belajar. Dalam hal ini siswa hanya diberikan sedikit bantuan dalam menyelesaikan permasalahan. Siswa akan lebih aktif dan kreatif dalam proses pembelajaran ini.

Menurut Ausubel cit. Winataputra (2007) belajar bermakna akan terjadi apabila informasi yang baru diterima siswa mempunyai kaitan erat dengan konsep yang sudah ada sebelumnya dan tersimpan dalam struktur kognitifnya. Pada penerapan pembelajaran berbasis masalah dengan metode proyek siswa akan menggunakan pengetahuan yang diperoleh sebelumnya dalam menyelesaikan masalah yang diberikan. Materi laju reaksi berkaitan dengan perhitungan mol dan konsentrasi larutan dalam sub bab pembuatan larutan, dimana materi tersebut telah diperoleh di tingkat sebelumnya.

Berbeda dengan hasil prestasi belajar afektif, pemberian metode yang berbeda ini tidak memberikan pengaruh yang signifikan. Dari hasil penelitian diperoleh rerata skor afektif untuk metode proyek dan eksperimen berturutturut adalah 115,3 $(\mathrm{SD}=8,7)$ dan 113,7 $(\mathrm{SD}=8,8)$. Keduanya memberikan hasil dengan kriteria baik. Pemberian metode tidak berpengaruh karena prestasi belajar afektif berkaitan erat dengan sikap, minat, konsep diri, nilai dan moral. Kan dan Akbas (2006) dalam penelitiannya menyatakan bahwa prestasi belajar afektif akan mempengaruhi prestasi belajar kognitifnya dalam hal ini komponen afektif berupa sikap dan konsep diri dalam proses belajar. 
ISSN: 2252-7893, Vol 2, No 32013 (hal 227-237)

http://jurnal.fkip.uns.ac.id/index.php/sains

\section{Pengaruh kreativitas terhadap prestasi belajar siswa}

Amabile (2005) dalam Affect and Creativity at Work menyatakan bahwa kreativitas memiliki dampak positif yaitu dapat meningkatkan kemampuan seseorang dalam menyerap suatu informasi, meningkatkan proses pembentukan struktur kognitif serta meningkatkan kemampuan berfikir divergen dalam menyelesaikan masalah. Kreativitas berkaitan erat dengan intelegensi seseorang yang akan berpengaruh terhadap perolehan prestasi belajar.

Berdasarkan hasil pengujian penelitian ini menunjukkan bahwa tidak ada pengaruh kreativitas tinggi dan rendah terhadap prestasi belajar kognitif maupun afektif siwa. Rerata prestasi belajar kognitif siswa dengan kreativitas tinggi dan rendah berturut-turut adalah $75,6(\mathrm{SD}=12,7)$ dan $72,6(\mathrm{SD}=14,7)$. Olatoye (2010) menyatakan bahwa kreativitas bukanlah bagian dari kemampuan seseorang dalam bidang kognitif (non-cognitive intelligence) tetapi berkaitan dengan emotional intelligence seseorang. Kemampuan ini cenderung mengacu pada interaksi sosial, perasaan, empati dan motivasi. Penelitian lain yang dilakukan oleh Hasanabadi (2011) menunjukkan bahwa tidak ada perbedaan pemilihan judul tugas akhir pada mahasiswa yang memiliki kreativitas tinggi dan rendah. Mahasiswa yang memiliki kreativitas tinggi cenderung memilih judul tugas akhir yang tidak terlalu sulit, selain itu mahasiswa yang memiliki kreativitas tinggi dan rendah tidak mempengaruhi terhadap hasil indeks prestasi kumulatif yang diperoleh.

Tidak adanya pengaruh kreativitas tinggi dan rendah terhadap prestasi belajar siswa dimungkinkan siswa terbiasa dengan pembelajaran dengan informasi berpusat pada guru, sehingga siswa tidak terbiasa dengan kegiatan belajar aktif. Tsai (2012) menyatakan bahwa salah satu komponen kreativitas yang berkaitan dengan kemampuan kognitif adalah kemampuan berfikir divergen. Kebiasaan siswa yang hanya menerima informasi ini menyebabkan pola berfikir kreatif siswa tidak berkembang, dan hanya terbiasa berfikir memusat (konvergen) dan mengakibatkan tidak ada pengaruh terhadap prestasi belajarnya. Penelitian lain yang dilakukan Wang (2011) menunjukkan bahwa kreativitas siswa berkaitan dengan jenis tes untuk memperoleh skor prestasi belajar. Kreativitas memiliki pengaruh positif pada bentuk tes lisan (oral examination), dan tidak berpengaruh ketika tes prestasi belajar berupa tes objektif (multiple choices).

\section{Pengaruh keterampilan menggunakan alat laboratorium terhadap prestasi belajar siswa}

Feyzioğlu (2009) menyatakan bahwa kegiatan belajar dalam laboratorium akan mendukung siswa untuk lebih memahami suatu konsep melalui proses empiris. Kegiatan ini akan menuntut siswa untuk membuktikan hipotesis, berfikir ilmiah, melakukan observasi dan menginterpretasi data. Hal ini akan berhasil jika didukung dengan pengaplikasian keterampilan dan teknik bekerja di laboratorium dengan baik oleh siswa.

Berdasarkan hasil pengujian diperoleh kesimpulan bahwa ada pengaruh keterampilan menggunakan alat laboratorium tinggi dan rendah terhadap prestasi belajar kognitif siswa. Rerata untuk siswa yang memiliki keterampilan menggunakan alat laboratorium tinggi dan rendah berturutturut adalah 79,3 $(\mathrm{SD}=11,8)$ dan 70,1 $(\mathrm{SD}=13,7)$. Data menunjukkan bahwa siswa yang memiliki keterampilan menggunakan alat laboratorium tinggi memiliki rerata yang lebih tinggi.

Kimia merupakan salah satu cabang dari IPA dalam pembelajarannya melibatkan siswa secara aktif melaksanakan proses ilmiah dengan memanfaatkan sarana laboratorium 
ISSN: 2252-7893, Vol 2, No 32013 (hal 227-237)

http://jurnal.fkip.uns.ac.id/index.php/sains

kimia di sekolah. Keterampilan menggunakan alat di laboratorium adalah salah satu faktor yang mempengaruhi keberhasilan proses belajar. Margono (2000) menyatakan bahwa keberhasilan suatu percobaan atau eksperimen kerap kali tergantung pada kemampuan memilih dan menggunakan alat dengan tepat. Keterampilan menggunakan alat meliputi keterampilan memilih alat-alat, mempersiapkan alat-alat, merangkai alat, menggunakan alat untuk tujuan percobaan.

Siswa yang memiliki keterampilan menggunakan alat tinggi akan lebih tepat dalam memilih, merangkai maupun menggunakan alat sesuai dengan fungsinya, sehingga proses pembentukan pengetahuan dalam struktur kognitifnya akan lebih baik.

Keterampilan menggunakan alat laboratorium tinggi dan rendah tidak memberikan pengaruh yang signifikan terhadap prestasi belajar afektif siswa. Data yang diperoleh menunjukkan bahwa rata-rata skor afektif untuk siswa yang memiliki keterampilan menggunakan alat laboratorium tinggi dan rendah berturut-turut adalah 115,6 $(\mathrm{SD}=9,2)$ dan 113,6 $(\mathrm{SD}=8,6)$. Hal ini dapat terjadi karena keterampilan menggunakan alat laboratorium lebih menitikberatkan pada kemampuan siswa secara fisik dalam hal penggunaan alat laboratorium secara tepat. Berbeda dengan penilaian afektif yang lebih menitikberatkan pada sikap yang ada pada diri siswa, sehingga keduanya tidak saling mempengaruhi.

\section{Interaksi antara pembelajaran kimia berbasis masalah menggunakan metode proyek dan eksperimen dengan kreativitas terhadap prestasi belajar siswa \\ Hasil pengujian menunjukkan bahwa tidak ada interaksi antara pembelajaran berbasis masalah menggunakan metode proyek dan eksperimen dengan kreativitas terhadap prestasi belajar kognitif siswa, tetapi ada}

interaksi terhadap prestasi belajar afektif. Pada penerapan pembelajaran berbasis masalah dengan merode proyek maupun eksperimen menuntut siswa untuk belajar secara aktif dalam menyelesaikan masalah. Siswa belajar dalam kelompok-kelompok kecil sehingga mereka dapat berinteraksi dengan anggota kelompoknya.

Pada ulasan sebelumnya dari penelitian ini menunjukkan bahwa pemberian metode yang berbeda memang memberikan pengaruh terhadap prestasi kognitif siswa, tetapi kreativitas tidak memberikan pengaruh yang signifikan terhadap prestasi belajar. Hasil prestasi belajar kognitif siswa yang memiliki kategori kreativitas tinggi ketika mendapat perlakuan dengan metode proyek dan eksperimen memiliki rerata yang tidak jauh berbeda yaitu 76,9 dan 73,2. Siswa yang memiliki kreativitas rendah ketika diberikan metode proyek dan eksperimen masingmasing memberikan rataan 72,6 dan 72,3. Data ini menunjukkan bahwa pada kedua metode siswa yang memiliki kreativitas tinggi selalu memperoleh prestasi yang lebih baik pada metode proyek maupun eksperimen.

Hal ini dimungkinkan karena kreativitas merupakan faktor internal yang dimiliki oleh siswa. banyak faktor yang dapat mempengaruhi proses pencapaian prestasi belajar baik dari dalam maupun dari luar diri siswa sehingga peneliti tidak dapat mengontrol faktor-faktor tersebut di luar kegiatan belajar mengajar.

Interaksi antara pembelajaran kimia berbasis masalah menggunakan metode proyek dan eksperimen dengan keterampilan menggunakan alat laboratorium terhadap prestasi belajar siswa

Berdasarkan hasil pengujian dapat diambil kesimpulan bahwa ada interaksi antara metode proyek dan eksperimen dengan keterampilan menggunakan alat laboratorium terhadap prestasi belajar kognitif siswa. Sejalan dengan adanya 
ISSN: 2252-7893, Vol 2, No 32013 (hal 227-237)

http://jurnal.fkip.uns.ac.id/index.php/sains

metode proyek dan eksperimen dalam fase menginvestigasi penyelesaian masalah maka keterampilan menggunakan alat laboratorium sangat dibutuhkan, karena hal ini merupakan faktor pendukung dalam proses menjawab pertanyaan yang telah diberikan. Siswa dituntut mampu menyelesaikan masalah dengan cara melakukan kegiatan-kegiatan laboratoris pada tahap ini.

Dalam penelitian ini keterampilan menggunakan alat dikategorikan dalam kategori tinggi dan rendah. Margono (2000), menyatakan bahwa keberhasilan suatu percobaan atau eksperimen kerap kali tergantung pada kemampuan memilih dan menggunakan alat dengan tepat. Siswa yang kurang terampil dalam menggunakan alat laboratorium dengan adanya metode pembelajaran yang diberikan diharapkan dapat meningkatkan prestasi belajar yang diperoleh. Dalam penelitian ini misalnya dengan penggunaan metode eksperimen, yaitu siswa dibimbing dalam melakukan percobaan. Di sisi lain siswa yang memiliki keterampilan menggunakan alat yang tinggi akan memperoleh hasil yang baik ketika dikenai metode proyek dalam pembelajaran.

\section{Interaksi antara kreativitas dengan keterampilan menggunakan alat laboratorium terhadap prestasi belajar siswa}

Fakta di lapangan menunjukkan bahwa ada siswa yang memiliki kreativitas tinggi dan rendah, ada pula siswa yang memiliki keterampilan menggunakan alat-alat laboratorium juga dalam kategori tinggi dan rendah. Siswa kreatif akan memiliki memiliki daya nalar tinggi, menyukai aktivitas yang bersifat kreatif, dan tidak hanya memperoleh pengajaran dari guru. Sikap kreatif siswa ini secara tidak langsung akan berhubungan dengan keterampilan menggunakan alat laboratorium.

Hasil pengujian menunjukkan bahwa terdapat interaksi antara kreativitas dengan keterampilan menggunakan alat laboratorium terhadap prestasi belajar kognitif siswa. Terdapat perbedaan prestasi belajar antara siswa yang memiliki kreativitas rendah dan keterampilan alat laboratorium tinggi dengan siswa yang memiliki kreativitas rendah dan keterampilan alat laboratorium rendah. Berdasarkan pengujian sebelumnya dalam penelitian ini tidak ada pengaruh kreativitas terhdap prestasi belajar siswa tetapi terdapat pengaruh dan interaksi keterampilan menggunakan alat laboratorium terhadap prestasi belajar kognitif siswa. Hal ini juga terlihat bahwa siswa yang sama-sama memiliki kreativitas rendah tetapi memiliki keterampilan menggunakan alat laboratorium yang berbeda memberikan perbedaan prestasi belajar yang signifikan pula.

Interaksi antara pembelajaran kimia berbasis masalah menggunakan metode proyek dan eksperimen, kreativitas serta keterampilan menggunakan alat laboratorium terhadap prestasi belajar siswa

Hasil pengujian menunjukkan bahwa tidak ada interaksi pembelajaran berbasis masalah dengan metode proyek dan eksperimen, kreativitas dan keterampilan menggunakan alat laboratorium terhadap prestasi belajar kognitif maupun afektif siswa. Penerapan pembelajaran berbasis masalah dengan metode proyek dan eksperimen pada materi laju reaksi menitikberatkan pada kegiatan dalam laboratorium dalam melakukan investigasi penyelesaian masalah yang diberikan.

Vygotsky menyatakan teori belajar dengan konsep scaffolding dan zone proximal development sejalan dengan penelitian ini, yaitu siswa diberi bantuan sedikit dalam penyelesaian masalah dan siswa diberikan masalah sedikit di atas pengetahuan yang telah ia ketahui sehingga siswa tertarik untuk belajar. Maka, dalam penelitian ini digunakan 
ISSN: 2252-7893, Vol 2, No 32013 (hal 227-237)

http://jurnal.fkip.uns.ac.id/index.php/sains

metode proyek dan eksperimen agar dalam proses pembentukan pengetahuan siswa dapat berlangsung dengan baik dan berpengaruh terhadap prestasi belajarnya.

Tidak adanya interaksi antara metode, kreativitas dan keterampilan menggunakan alat laboratorium terhadap prestasi belajar kognitif dan afektif menunjukkan bahwa siswa yang memiliki kreativitas dan keterampilan menggunakan alat tinggi memperoleh hasil yang lebih baik dalam kedua metode yang diberikan. Hal ini dimungkinkan siswa yang memiliki kreativitas tinggi akan melakukan kegiatan belajarnya secara aktif. Begitu pula dengan siswa yang memiliki keterampilan menggunakan alat laboratorium tinggi akan melakukan kegiatan percobaan dengan tepat sehingga pembentukan pengetahuan dalam struktur kognitifnya akan lebih baik.

\section{Kesimpulan dan Rekomendasi}

Berdasarkan hasil analisis dan pembahasan diperoleh kesimpulan sebagai berikut: 1) ada pengaruh pembelajaran kimia berbasis masalah menggunakan metode proyek dan eksperimen terhadap prestasi belajar kognitif siswa, namun tidak ada pengaruh terhadap prestasi belajar afektif; 2) tidak ada pengaruh kreativitas terhadap prestasi belajar kognitif dan afektif siswa; 3) ada pengaruh keterampilan menggunakan alat laboratorium terhadap prestasi belajar kognitif siswa, namun tidak ada pengaruh pada prestasi belajar afektif; 4) tidak ada interaksi antara pembelajaran kimia berbasis masalah menggunakan metode proyek dan eksperimen dengan kreativitas terhadap prestasi belajar kognitif dan afektif siswa; 5) ada interaksi antara pembelajaran kimia berbasis masalah menggunakan metode proyek dan eksperimen dengan keterampilan menggunakan alat laboratorium terhadap prestasi belajar kognitif siswa, namun tidak ada interaksi terhadap prestasi belajar afektif; 6) ada interaksi antara kreativitas dan keterampilan menggunakan alat laboratorium terhadap prestasi kognitif siswa, namun tidak ada interaksi pada prestasi afektif; 7) tidak ada interaksi antara pembelajaran kimia berbasis masalah menggunakan metode proyek dan eksperimen, kreativitas dengan keterampilan menggunakan alat laboratorium terhadap prestasi kognitif dan afektif siswa.

Rekomendasi dari hasil penelitian yang telah dilakukan adalah sebagai berikut: 1) pembelajaran kimia berbasis masalah dengan metode proyek dan eksperimen memberikan hasil positif terhadap prestasi belajar kognitif siswa; 2) penerapan pembelajaran berbasis masalah menggunakan metode proyek dan eksperimen dengan memperhatikan faktor kreativitas dan keterampilan menggunakan alat laboratorium berpengaruh terhadap prestasi belajar siswa; 3) adanya kelemahan pada skala penilaian afektif perlu dilakukan observasi dan wawancara untuk memperkuat penilaian aspek afektif.

\section{Daftar Rujukan}

Amabile, TM. (2005). Affect and Creativity at Work. Administrative Science Quarterly, 50: 367-403

Arends, RI. (2007). Learning to Teach. New York: Mc.Graw Hill

Bilgin, I. (2009). The Effects of Problem Based Learning Instruction on University Student's performance of Conceptual and Quantitative Problems in Gas Concepts. Eurasia Journal of Mathematics, Science and Technology Education, Vol. 5 153-164

Dahar, RW. (1989). Teori-Teori Belajar. Jakarta: Erlangga

Ebrahimi, S. (2012). Comparing the Effect of $5 \mathrm{E}$ and Problem Solving 
ISSN: 2252-7893, Vol 2, No 32013 (hal 227-237)

http://jurnal.fkip.uns.ac.id/index.php/sains

Teaching Methods on the Students' Educational Progress in the Experimental Sciences Course. Journal of Basic and Applied Scientific Research, Vol.2 (2)

Feyzioğlu, B. (2009). An Investigation of the Relationship between Science Process Skills with Efficient Laboratory Use and Science Achievement in Chemistry Education. Turkish Science Education, Vol. 6, Issue 3

Hamalik, O. (2001). Proses Belajar Mengajar. Jakarta: Bumi Aksara

Hasanabadi, A. (2011). Relationship between Master Student's Creativity and Thesis Topic. European Journal of Social Sciences, Vol.26. No.4. 609-615

Hofstein, A, Lunetta, VN. (2003). The Laboratory in Science Education: Foundations for the Twenty-First Century. Wiley Periodicals, Inc. Sci $E d, 88: 28-54$

Kan, A, Akbas, A. (2006). Affective Factors That Influence Chemistry Achievement (Attitude and Self Efficacy) and The Power Of These Factors To Predict Chemistry Achievement-I. Journal of Turkish Science Education, Vol. 3, Issue 1

Margono, H. (2000). Metode Laboratorium. Malang: Universitas Negeri Malang

Munandar, U. (2009). Pengembangan Kreativitas Anak Berbakat. Jakarta: Rineka Cipta

Olatoye, RA. (2010). Emotional Intelligence, Creativity and
Academic Achievement of Business Administration Students. Electronic Journal of Research in Educational Psychology, Vol. 8 (2), 763-786

Rusman. (2010). Model-Model Pembelajaran Mengembangkan Profesionalisme Guru). Jakarta: Raja Grafindo Persada

Sagala, S. (2010). Konsep dan Makna Pembelajaran. Bandung:Alfabeta

Slavin, R.E. (1994). Educational Psichology Theory and Practice. Massachussets: Paramount Publishing

Sola, AO, Ojo, E. (2007). Effects of project, inquiry and lecture-demonstration teaching methods on senior secondary students'achievement in separation of mixtures practical test. Educational Research and Review, Vol. 2 (6), pp. 124-132

$\begin{array}{rr}\text { Suparno, P. (2007). } & \text { Metodologi } \\ \text { Pembelajaran } & \text { Fisika } \\ \text { Konstruktivistik } & \text { dan } \\ \text { Menyenangkan. } & \text { Yogyakarta: } \\ \text { Sanata Dharma } & \end{array}$

Tsai, KC. (2012). The Value of Teaching Creativity in Adult Education. International Journal of Higher Education. Vol. 1, No. 2

Wang, AY. (2011). Contexts of Creative Thinking: A Comparison on Creative Performance of Student Teachers in Taiwan and the United States. Journal of Cross-Cultural Studies, Vol. 2, Issues 1

Winataputra, US. (2007). Teori Belajar dan Pembelajaran. Universitas Terbuka 